\title{
Soil Is an Essential Component of the Biosphere and the Global Food System (Critical Assessment of the Situation)
}

\author{
D. M. Khomiakov* \\ Department of Soil Science, Moscow State University, Moscow, Russia \\ *e-mail:khom@soil.msu.ru \\ Received May 10, 2020; revised May 15, 2020; accepted May 17, 2020
}

\begin{abstract}
Soil is the basis of food systems at all levels. Preservation of ecological functions of the soil cover and its status in areas newly developed or excluded from agriculture determines the rate and occurrence time of ecological risks and threats to food security. The global role and cost of soil resources increase. Russia is characterized by the maximal area of soil cover: approximately $14.5 \times 10^{6} \mathrm{~km}^{2}$ or one sixth of the soil cover of the Earth. Soils are underestimated as a unique national wealth and strategic resource. The amounts of applied agrochemicals are insufficient for the reproduction of soil fertility. The food security in the country is achieved and food products are exported due to nonreimbursable expenses of reserves of soil fertility. There are no state documents, which clearly and unequivocally determine the amount and location of arable soils and farm lands required for the modern agriculture and for solution of problems of sustainable development.
\end{abstract}

Keywords: soil, soil cover, food systems, green economy, climate-neutral agriculture, sustainable development goals

DOI: $10.3103 / \mathrm{S} 0147687420040055$

\section{INTRODUCTION}

Food, national, economic, and environmental safety, as well as the security of life and health of citizens, are closely related. This was once again proven during the economic crisis and the coronavirus pandemic of 2020.

All areas of the national economy, including agriculture, are affected. Reduced production and logistic failures affect the global food balance: countries restrict their import and export, replenish strategic reserves, and set limits and quotas of the consumption by the population, which in turn tries to realize abnormal demand. Food losses in the production-distribution-exchange-consumption chain increase. According to data from the World Bank, there are more than 2.1 billion poor people and 770 million people suffering from extreme poverty on Earth. The increase in their number is one of the main dangerous manifestations of the crisis and its consequences.

The problem of hunger on Earth has not been solved [31]. At the virtual meeting of the UN Security Council held on April 2, 2020, a warning about a possible upcoming famine of biblical proportions was made. More than 820 million people suffered from hunger in 2019, and another 265 million people will be added by the end of this year. Hence, it may be assumed that the number of inhabitants of the planet experiencing strong food insecurity may increase from the previously mentioned two billion to three billion people (of 7.8 billion currently living people).

The Annual Report of the International Food Policy Research Institute (IFPRI) Global Food Policy Report 2020: Building Inclusive Food Systems [21] declares that the adjustment of food systems to the poor and vulnerable segments of the population is a priority global social task, but it can only be solved if there are soil and water resources that may be provided to small family farms for agricultural production.

An independent information platform WEF Nexus (water, energy, and food resources and security) appeared in 2011 and successfully functions. Energy processes also include climatic, all alternative, and atmospheric processes. The aim is to obtain objective information for decisions that ensure the well-being and empowerment of man, poverty alleviation, and sustainable development with increasing demand for all resources. A systemic approach to the study and solution of problems is mandatory, because this is the only way to achieve the maximal efficiency and balance of the use of resources at the global, regional, and local levels, taking into account development prospects $[20,32]$. For solution implementation, the WEF Nexus platform reasonably distinguishes the concepts of soil and land. 
An analytical note published in May 2020 states that soil is the missing link in the water-energy-foodenvironment nexus; even the EU considers modern inefficient soil management as an example of a serious anthropogenic impact on the biosphere that affects the viability and comfort of all socioecological systems. The conclusion is: more attention should be paid to soil during the development of the policy for achieving sustainable development goals (SDGs) [25]. This direction of activity is based on the principle of improving the quality of man life without destroying the natural environment (biosphere). The UN organization has formulated 17 main sustainable development goals for the period to 2030. The International Resource Panel (IRP) was founded according to the United Nations Environment Program (UNEP) to perform researches for rational and safe use of natural resources. Its document is called Land and Soil Restoration for Achieving the Sustainable Development Goals. An International Resource Panel (2019) shows that land restoration, landscape preservation, fertility maintenance, and reclamation and rehabilitation of soils are the basic aspects included in all SDGs. Decisionmakers must understand that all components (subsystems) in complex ecological, economic, and social systems are interrelated [24].

The problems of objective study of the composition, structure, and the forming factors of food systems, including soil and soil cover, which are the basis of global and national security, are still urgent.

The methodology and methods of this work consisted in collecting, summarizing, analyzing, and evaluating the results of practical and theoretical researches. We studied normative legal acts, documents prepared by high-level experts, and international and national strategic planning materials-more than 350 documents in total. We evaluated the current versions of regulatory legal acts with amendments and additions, which came into force by July 1, 2020. All the calculations were based on official statistical information.

\section{RESULTS}

\section{Soil Resources and Sustainable Development. Ecological Functions of Soils}

On March 1, 2019, the UN General Assembly named the period from 2021 till 2030 a Decade of Ecosystem Restoration for Achieving the SDGs. It should be pointed out that the soil is a component of all land ecosystems of a particular hierarchical level as an integral, mandatory, and irreplaceable subsystem.

Soils are characterized by particular fertility and should be assigned to extremely important nonrenewable resources. For their sustainable management, the Council of the Food and Agriculture Organization of the United Nations (FAO) established the Global Soil Partnership (GSP) in 2012. With the help of a scientific advisory body - the Intergovernmental Technical
Panel on Soils-it revised the World Soil Charter (WSC), a political document adopted by the FAO Conference in November 1981.

A document called Status of the World's Soil Resources (SWSR)-Main Report was prepared by FAO. It describes and ranks the top ten threats to soils, which affect ecosystem functions at the global level and in each region. The report describes direct and indirect loads on soils, as well as approaches and means to control their degradation [29]. To intensify this activity, the Voluntary Guidelines for Sustainable Soil Management were announced (approved by the 155th session of the FAO Council, Rome, December 5, 2016). A global task was set: to reveal, strengthen, and maintain the potential of soils not only for food production, but also for preserving water resources, biodiversity, reducing carbon emissions, and improving the sustainability of ecosystems in a changing climate [33].

For the implementation of this document, an International Code of Conduct for the Sustainable Use and Management of Fertilizers was elaborated [3]. Compensation of mineral nutrients removed with harvest and/or excluded from turnover is the basis for maintaining their zero or positive balance in agrocenoses, which provides the reproduction of soil fertility and the possibility to obtain high-quality agricultural products.

Russian scientists have done much to substantiate the fundamental laws and principles: soil and soil cover (soil envelope of the Earth, geoderma, or pedosphere) are an integral part of the biosphere, an essential component of the environment, and the basis for the functioning of food systems [2-4, 6, 15-17]. In case of the loss of ecological functions of soils, the sustainable development will fail and the very existence of the biosphere will be endangered. Foreign experts believe that it is difficult to overestimate the place and role of soil in achieving the SDGs, but it is still underestimated. The task of the scientific community is to change the viewpoint of decisionmakers $[1,8,9,22$, $23,25,28]$.

The document Agricultural Outlook 2019-2028 is a result of joint efforts of the Organization for Economic Cooperation and Development (OECD) and FAO. It was prepared with the participation of experts of governments of member countries and organizations, specializing in exchangeable and primary commodities [26]. The forecasts were made just prior to the economic crisis and the coronavirus pandemic.

In the next decade, the need for food will grow. The consumption of basic foodstuffs per capita will remain the same. The demand for them in the world has reached its maximum, which is related to low incomes and a slight economic growth.

(It should be mentioned that at the beginning of the crisis related to coronavirus, when the global market was open and the accumulated reserves were not used up, world food prices did not increase sharply. As 
a result of the lower business activity, some of produced products remained unclaimed and were utilized. The share of counterfeit goods increased. The long-term trend remained unchanged: a significant number of people are malnourished and starving, and their amount increases. Food prices rise now without an absolute connection with the cost of energy resources. Protectionism, accumulation of excess (strategic) reserves of products by countries, excessive demand of the population, new strict quarantine measures of the second coronavirus wave, and failures in production and logistics can provoke a deficit of food products (global, regional, and local) on the background of a stagnating economy and aggravation of resource-environmental problems.)

Almost the total projected rise in fish and seafood supplies in commercial fishery will be related to aquaculture, which will increase its portion in the total production to about $55 \%$ by 2028 .

The share of forage crops (corn and soy) in the global structure of crops will increase. The rise in the consumption of cereals for forage will exceed that of cereals for food. The total agricultural production will rise by $15 \%$, while the total area of used land in the world will remain the same. The projected increase in crop production may be primarily related to higher yields and more intensive agricultural technologies due to innovations. The number of livestock will rise, and the greater amount of forage will be used more effectively.

Man is also a part of the biosphere. At the present time, the total mass of people as a biological species is estimated at $300 \times 10^{6}$ tons. A balanced food, containing the necessary amount of animal protein with a complete number of amino acids, is needed every day to maintain the life of the population. The required amino acids include essential ones, which are absent in plant food and are not synthesized by man himself during digestion.

According to various estimates, at least $95-97 \%$ of food consumed in the world is received as a result of agricultural production on land with the use of soils. The rest portion is related to resources of the hydrosphere, including the world's oceans.

The main conclusion drawn from the document is that the problem of hunger remains, is not solved, and will increase. Its urgency may be reduced by using intensive, innovative, and knowledge-intensive agricultural technologies. The world's soil resources are already deficient. "To what extent?" is the reasonable question.

UNEP developed a concept of a safe working environment (SWE) [19]. It is proposed to use no more than 0.2 ha of arable soil per person for purposes of consumption by 2030. Exceeding this norm will be an unacceptable risk and will result in irreversible damage: a decrease in biodiversity, the release of carbon dioxide, the disturbance of the water and nutrient cycle, the involvement of new lands in agriculture, and the reduction of soil areas in natural biogeocenoses. In many cases, agricultural lands are enlarged at the expense of forests, in tropical regions in particular. (For example, there were strong fires in South America in summer and fall of 2019, when plots were cleaned for soybean crops. It is exported to Europe and used in livestock breeding. It is necessary to plow about $16 \times 10^{6}$ ha of soils (the area of four small European countries) to get additional $32 \times 10^{6} \mathrm{t}$ of soybeans per year. There are no such resources in the EU: its area is occupied by plowed land and perennial plantations ( $25 \%$ of the total area), pastures (17\%), and forests (34\%) [12].)

Monitoring of the global land use by countries and regions should show whether they are within or outside their SWE. The proposed measures include: intensification of agricultural production by environmentally and socially acceptable ways; investment in the restoration of degraded soils and landscapes; land use planning and improvement of land management; minimizing of the expansion of residential areas at the expense of fertile soils, etc. Economic sanctions are not excluded $[19,25]$. The mean SWE index in the EU is $0.35 \mathrm{ha} /$ person and varies from 0.06 in the Netherlands and Belgium to 0.15 in Austria and Germany, and to 0.44 in Hungary and Bulgaria. In Russia, the cropland is about $80 \times 10^{6}$ ha, fallow land is $15 \times 10^{6}$ ha, and the population is $146 \times 10^{6}$ persons. The real SWE index is $0.65 \mathrm{ha} /$ person [10-13].

The intensification of agricultural production in the Netherlands with an area smaller than Moscow oblast resulted in a record volume of agricultural export in 2019: 94.5 billion Euros. However, in 2020, a large mass of vegetables and floriculture products unclaimed due to the pandemic was composted, and the industry met with losses.

The export of agricultural products from Russia in 2018 and 2019 reached US \$25 billion and US \$30 billion of import [13]. Similar volumes of export are planned for the current year, while import will decrease due to the crisis.

According to estimates by the UNEP, the area of the plowed land in the world may be safely increased to only $1640 \times 10^{6} \mathrm{ha}$. Thus at the SWE of $0.2 \mathrm{ha} /$ person, this corresponds to the world population of 8.2 billion persons. In the 1970s, limits to growth were discussed [7]. These data often appeared in the results of mathematical modeling. According to our forecasts, the growth rate of the population will result in its increase by about one billion people by 2030 (within a period of ten years). To meet the need for food, it is necessary to introduce another $200 \times 10^{6}$ ha of arable soil into agriculture without loss of the $1550 \times 10^{6}$ ha already used.

In case of an inertial scenario, the expected global demand for soil resources will be beyond the SWE well before 2050. By this year, the potential increase in the area of arable land in the world may be no more than 
$500 \times 10^{6}$ ha. Soil fertility will decrease in the area of about $900 \times 10^{6}$ ha due to stronger degradation processes, if their modern rate is preserved. These areas will be then partially or completely excluded from agriculture. It is possible that in a number of countries, primarily in the EU, the planned large-scale measures for the conservation of agricultural landscapes according to the Green Deal program will start from 2021.

It may be concluded that even now, there are practically no free reserves of arable soils in the world. So the status of the areas reintroduced in or withdrawn from agricultural use and of their soil cover will determine start time and the rate of ecological risks, as well as of risks and threats to food security at various levels, including the global one.

Restoration, recultivation, remediation, and alternative use of landscapes, revitalization of rural areas, and enlargement of sensitive and specially protected areas and reserves are topical issues in the current and post-crisis agenda for all countries according to the creation of green economy and to biodiversity conservation programs.

\section{Assessment of the Role and Place of Soil in the Strategic Development of Russia (National Level of the Control)}

The global role of soil resources increases with population growth, the development of the processes of their degradation and loss, and the inability of the soil cover of the Earth to adequately perform biosphere functions. Russia is characterized by the maximal soil cover of about $14.5 \times 10^{6} \mathrm{~km}^{2}$ or one-sixth of the planet area. Soils of our country are a unique and yet undervalued national wealth. The concept of soil systematically disappears from the legal framework. Consequently, soil resources are not taken into account in the real financial-economic activities. This is confirmed by the analysis of procedures, rules, and regulations with the account of the history of their changes. The problem of creating adequate institutions and mechanisms, which can meet global environmental challenges and provide the implementation of the SDGs, is urgent in many countries [27].

The Civil Code of the Russian Federation (part 1, article 261), Federal Law no. 51 of November 30, 1994, defines a land plot as an object of the right of ownership. Unless otherwise decreed by the law, the right of ownership to the land plot is shared to the surface (the soil) layer, water bodies, and plants within the boundaries of this plot (paragraph 2). The owner of the land plot has the right to use at his own discretion everything, which is located over and under its surface, unless otherwise stipulated by the laws on the mineral wealth and on the use of the air space and by other laws and it does not violate the rights of other persons (paragraph 3).

Federal Law no. 2395-1 of February 21, 1992, On the Subsoil, states that the subsoil is a part of the earth crust located below the soil layer or, in its absence, below the earth surface and the bottom of reservoirs and watercourses, extending to depths accessible for geological study and development. The soil layer itself is not defined.

In Federal Law no. 218-FZ of July 13, 2015, On the State Registration of Immovable Property, the word soil is not used at all, and the land plot is determined as a kind of immovable property object.

The Land Code of the Russian Federation no. 136-FZ of October 25, 2001, was revised many times during the 19-year period since its first version came into force. Significant amendments and additions were made (more than 270 by more than 130 Federal laws); chapters, articles, and paragraphs were added or removed; and revised versions appeared (114). In the current version (article 6, paragraph 3), the objects of land relationships include: (1) land as a natural facility and natural resource, (2) land plots, and (3) parts of plots of land. A land plot as an object of the right of ownership and of other rights related to land and provided by this code is an immovable property, which represents a part of the ground surface and is characterized by features that enable its definition as a specific item of property.

The goals of land preservation (article 12) are to prevent and eliminate pollution, depletion, degradation, damage, and destruction of land and soil and other negative effects on land and soil, as well as to ensure the rational use of land, for restoring soil fertility on agricultural land and for land reclamation in particular. This article for the first time contains the terms soil and soil fertility. The former is not adequate to the term land, as it can be seen from the context. Which is the meaning of these notions? Their definition is given in state standards.

The meaning of the concept of land is defined in the current GOST 26640-85 (ST CMEA 4472-84). State Standard of the USSR. Lands. Terms and definitions (approved and brought into force by the Decree of the State Standard of the USSR of October 28, 1985, no. 3453). Land is the most important part of the natural environment, characterized by space, topography, climate, soil cover, vegetation, subsurface resources, and water; it is the main mean of production in agriculture and forestry, as well as the spatial basis for the disposition of enterprises and organizations of all sectors of the national economy.

According to GOST 27593-88 (ST CMEA 529885). State Standard of the USSR. Soils. Terms and Definitions (approved and brought into force by the Decree of the State Standard of the USSR no. 326 of February 23, 1988), soil is an independent naturalhistorical body formed on the Earth's surface as a result of a long-term effect of biotic, abiotic, and anthropogenic factors and consisting of solid mineral and organic particles, water, and air, and having specific genetic-morphological features and properties, 
which create appropriate conditions for plant growth and development.

It is clear that it is improper to replace one concept by another. But what is soil from the point of view of law?

Federal law no. 206-FZ of July 21, 2014 (revised on April 23, 2018), On Plant Quarantine, defines that soil is a component of the natural environment, consisting of mineral and organic components, which support the vital activity of plants. The term soil does not imply peat, sand, deep ground layers, compost, or artificially created plant habitat (article 2, paragraph 32). According to paragraph 29 of article 2, soil is an element of quarantined products.

The order of Ministry of Russia no. 316 of July 11, 2018, On Changes in the Calculation Method of Damage Caused to Soil as a Protected Object of the Environment, approved by the Order no. 238 of the Ministry of Natural Resources of the Russian Federation of July 8, 2010, defines the cost of damage to soils as a result of their pollution, spoilage, and destruction of the fertile layer. In this order, soil is determined as a component of the natural environment formed on the Earth surface and consisting of mineral substances of the rock, underlying it, organic substances formed during the decomposition of dead remains of animals and plants, water, air, living organisms, and their metabolic byproducts, and characterized by fertility.

Fertility is certainly an important characteristic of soils, but it is not the only one. All these definitions do not take into consideration a wide range of ecological functions of soils as an integral part of the biosphere, as well as of ecological services. (The latter concept was specially introduced to facilitate the elaboration and implementation of economic mechanisms for recording and evaluating the cost of soil and other natural resources, and financial mechanisms for the collection and distribution of rent.) Therefore, soils and soil cover are now undervalued as a component of the environment, and the sum of recovery is significantly reduced.

Quality standards have not yet been determined for soils, as for many other components of the environment. Decree of the Government of the Russian Federation no. 149 of February 13, 2019, On the Elaboration, Establishment, and Revision of Environmental Quality Standards for Chemical and Physical Parameters of the Status of the Environment and on the Approval of Regulatory Documents in the Field of Environment Protection, Determining Technological Parameters of the Best Available Technologies, contains the following provisions:

(i) quality standards are determined for assessing the status of the environment in order to provide favorable conditions for living activity of man, rational use of natural resources, and preservation of natural ecological systems and the genetic fund of plants, animals, and other organisms (paragraph 2); (ii) quality standards are elaborated and established for particular components of the natural environment, including soils (lands) (paragraph 4).

Soil and land are different components of the environment, but they are identical in the text of the document (?). Legal uncertainty increases.

Decree of the President of the Russian Federation no. 176 of April 19, 2017, On the Strategy of Environmental Security of the Russian Federation for the Period to 2025, defines that it is an integral part of national security. It is pointed out that a tendency to deterioration of land and soil status is preserved almost in all regions of the country. Land and soil degradation is assigned to global and internal challenges, and the concepts of these two objects are distinguished.

Federal law no. 7-FZ of January 10, 2002 (revised on July 26, 2019), On Environmental Protection (hereinafter 7-FZ), introduced the following concepts (article 1):

(i) natural environment (hereinafter nature) is a combination of components of natural environment, natural, and natural-man-made facilities;

(ii) components of natural environment are the ground, subsoil, soils, surface and ground water, atmospheric air, flora, fauna, and other organisms, as well as the atmospheric ozone layer and near-Earth space, which together provide favorable conditions for life on the Earth.

The law also states that natural landscape is an area that has not undergone modification as a result of economic or other activity and is characterized by a combination of particular types of topography, soils, and vegetation formed under the same climatic conditions.

In the law, land and soil are assigned to different components. The meaning of the terms is not explained. Further in the text, there are the terms soil cover (article 16.3, paragraph 6 and article 62.1, paragraph 3.1) and fertile soil layer (article 40, paragraph 3).

Rare and disappearance threatened soils shall be subject to state protection and a Red Book of Soils of the Russian Federation and Red Books of Soils of Russian regions shall be instituted for soil recording and protecting purposes; the procedure for their keeping is determined by the soil protection legislation (article 62, paragraph 1).

The procedure for assignment of soils to rare and disappearance threatened and also the procedure for setting up the regimes of use of the land plots, the soils of which are assigned to rare and disappearance-threatened, are established by the legislation (article 62, paragraph 2).

Without determining what soil is, it is impossible to comply with these provisions.

Model law on soil protection (adopted in St. Petersburg on October 31, 2007, by the order no. 29-16 at the 29th Plenary Meeting of the Interparliamentary 
Assembly of the states-participants of the CIS) is aimed to regulate relations, arising from the implementation of state policy on soil protection and of state monitoring of the soil status, of the compliance of subjects of economic and other activities with requirements for the prevention of soil pollution and degradation, and for the preservation and restoration of soils and their fertile layer. It is not mandatory in the Russian Federation.

There is a draft law no. 83224-3 On Soil Protection in the archive of the State Duma of the Federal Assembly of the Russian Federation. It was first introduced on April 19, 2001, but did not pass even the first reading.

\section{Soil in Agricultural Production (Use Management)}

The development of Russian agroindustrial complex is determined by two closely interrelated main factors: rational use of soil, area, and hydrothermal (agroclimatic) potential and an increase in the labor productivity. These factors now determine whether the country can develop a sustainable food system and ensure the expected rise in export within the mediumterm period.

State documents, which clearly and unambiguously determine the location and area of arable soils and agricultural land required for the modern agriculture and sustainable development, are still absent in Russia. Unfortunately, these problems are not solved in the Draft Resolution of the Government of the Russian Federation On Approval of the State Program for Effective Involvement of Agricultural Land in the Rotation and for the Development of the Reclamation Complex of the Russian Federation for 2021-2030 (elaborated according to the Instruction of the Government of the Russian Federation no. DM-P13-62pr of October 2, 2019).

Agricultural facilities should be used with the compliance of the requirements of environmental protection, and measures must be taken to protect lands, soils, water bodies, plants, animals, and other organisms from the negative impact of economic and other activities on the environment (7-FZ, article 42, paragraph 1).

In Federal law no. 101-FZ of July 16, 1998, on State Regulation of Securing Fertility of Agricultural Land, the term soil is absent even in the title. Its article 1 legalizes incorrect, in our opinion, thesis that the fertility of lands of agricultural purpose is the capability of the soil to satisfy the need of agricultural crops for nutrients, air, water, heat, and biological and physicochemical medium and to provide the harvest of agricultural crops.

Reproduction of fertility of agricultural lands consists in the preservation and increase of fertility of agricultural lands by regular agrotechnical, agrochemical, ameliorative, phytosanitary, antierosion, and other measures.
Fertility is a feature of soils and not of lands. Its reproduction means a particular system of activities and measures, but they cannot be determined without the expertise of specialists for each particular case and a corresponding project. It may be only elaborated if there are technologies that are already scientifically based on the data of agronomic experiments and approved. The final expression other measures makes the list open, which is absolutely unacceptable: there may be more than one interpretation of this norm.

According to article 8 of the analyzed law, owners and users, including lessees, of land plots are obliged to:

(i) realize agricultural production by methods, which provide reproduction of fertility of agricultural lands and exclude or limit the adverse effects of such activities on the environment (there is a question: which are these ways, and who and how determines them?);

(ii) observe the rules and regulations to ensure the fertility of agricultural land (the question is: which rules and regulations, and who and how sets them?); and

(iii) submit information on used agrochemicals and pesticides to executive agencies according to the established procedure; assist soil, agrochemical, phytosanitary, and ecological-toxicological surveys of agricultural land.

Article 43 of the 7-FZ states that during land amelioration, design, construction, reconstruction, commissioning, and operation of reclamation systems and stand-alone hydraulic engineering facilities, measures must be taken to protect water bodies, lands, soils, forests and other vegetation, and animals and other organisms, as well as to prevent other negative effects on the environment.

Federal law no. 4-FZ of January 10, 1996 (revised on December 27, 2019), On Land Reclamation states that it is performed in order to increase the productivity and sustainability of agriculture, to ensure guaranteed agricultural production on the basis of preserving and increasing land fertility, as well as to create the necessary conditions for the involvement of unused and unproductive lands in agricultural rotation and for the formation of a rational land structure (article 1). Article 2 contains definitions of reclaimed lands: these are lands, insufficient fertility of which is improved by reclamation measures, and lands, on which reclamation measures have been performed.

Land reclamation is a radical improvement of lands by hydrotechnical, clearing, chemical, antierosion, agroforestry, agrotechnical, and other reclamation measures. They include works to improve chemical and physical soil properties.

This law again contains the incorrect term land fertility. Melioration itself is related to soils, because it is aimed at the improvement of their status and an increase in fertility. Logically, any arable soils, on which modern landscape-adaptive (or soil protective) systems of agriculture and forage production are used, are reclaimed (improved). That is to say, the applica- 
tion of agricultural technologies and the organization of the area result in higher fertility and in a rise in crop yields. This is confirmed by GOST R 58330.2-2018 National Standard of the Russian Federation. Reclamation. Types of Reclamation Activities and Works. Classification. It was brought into force from July 1, 2019 (approved by Rosstandart order no. 1143-st of December 25, 2018).

Further in the text of the law no. 4-FZ, the term soil is mentioned in a number of articles: protection of soils from water erosion, prevention of degradation and erosion of soils (articles 2 and 7), soil protection functions (article 2), nutrient regime of soils (articles 6 and 30), reclamation treatment of solonetzes; loosening, sand application, clay application, earth mulching, trenching, and primary tillage (article 8 ).

We present the full text of article 9. Chemical land reclamation consists in a complex of reclamation measures to improve chemical and physical soil properties. Chemical amelioration of lands includes lime, phosphorus, and gypsum application to soils. It is clear that the term land is unnecessary here.

There are ecological requirements for land reclamation activities. They should not result in deterioration of the environment (article 32), are performed in compliance with the requirements of land, water, and forest legislation, as well as of the legislation of the Russian Federation on the environmental protection and on subsoil, flora, and fauna. The state monitoring of reclaimed land is a system of their status control. Changes are evaluated on the basis of the results. The objects are represented by all reclaimed lands in the Russian Federation (article 21). In fact, a special procedure for the state monitoring of reclaimed land is now absent: it is performed within the state monitoring of agricultural lands.

There is still an open question about the procedure of assignment of plots to reclaimed lands and the possibility of performance of soil reclamation activities on them. Land reclamation is performed on the basis of projects elaborated according to feasibility studies and taking into account construction, ecological, sanitary, and other norms and regulations (article 25). These actions undoubtedly require digital geospatial data and electronic maps, which include geodetic-precise information about the soil cover and its functioning. In the ideal case, 2D and, where possible, 3D digital soil models of various levels and scales (local, regional, etc.) should be available.

The Order of the Ministry of Agriculture of the Russian Federation no. 255 of May 15, 2019, on Approval of the Procedure for Development, Coordination, and Confirmation of Land Reclamation Projects, mentions particular soil-reclamation conditions, which are used to substantiate the need to choose reclamation type during the project preparation. This term is not found in other regulatory documents.
Decree of the Government of the Russian Federation no. 1662-R of November 17, 2008, On the Concept of Long-Term Socio-Economic Development of the Russian Federation until 2020, states that the main goals of the state agrarian policy include more effective use and reproduction of land resources based on improving soil fertility and developing land reclamation. The rate of mineral fertilizers in active substances (a.s.) per 1 ha of agricultural crops should increase from $33 \mathrm{~kg}$ in 2007 to $50 \mathrm{~kg}$ in 2011, and to $130-150 \mathrm{~kg}$ in 2020 (section 8).

The results of our analysis of the real situation according to data of the Russian Federal State Statistics Service [10, 11, 13] are given in Table 1. The Service takes into account only fertilized areas: their portion in 2007 was $39 \%$ of the total area of crops. From 2000 till 2019, this parameter gradually increased from $27 \%$ to $60 \%$ (it averaged $70 \%$ in 1986-1990). Therefore, the data obtained by an incorrect method are always significantly overestimated. We used the correct approach, taking into account the total area of crops and the amount of mineral fertilizers applied. Despite the reduction of croplands, the rate of applied mineral fertilizers decreased three times from $110 \mathrm{~kg}$ a.s./ha. This aim of the state agrarian policy was not achieved.

The Department of Crop Production of the Ministry of Agriculture of the Russian Federation stated in October 2019 that $61.3 \times 10^{6}$ tons of a.s. of the three main mineral nutrients (recalculated per $\mathrm{N}, \mathrm{P}_{2} \mathrm{O}_{5}$, and $\mathrm{K}_{2} \mathrm{O}$ ) had been removed from the soil with the crop yield from 2014 till 2018. The application of a.s. with organic and mineral fertilizers comprised $25.0 \times 10^{6}$ tons. The difference over the five-year period was $36.3 \times 10^{6}$ tons of a.s. These calculations do not include the behavior of mineral fertilizers in soil, coefficients of assimilation of nutrients by plants, their migration in the soil profile, losses (including gaseous losses for nitrogen), and other expenditure items of the balance of elements in agrocenoses. The area of arable land should be calculated by summing up the sown and fallow areas (losses also occur on fallow lands). In addition to agrochemical measures, there are also other income items of the balance.

Beginning from the mid-1990s, there is a negative uncompensated balance of the main mineral nutrients of agricultural crops in arable soils. We estimate it at 80-100 kg a.s./ha per year. Calcium and magnesium are constantly removed from the plowed soil layer due to intraprofile migration (leaching) and harvesting. The use of mineral fertilizers and acid precipitation enhance this process. Lime application is assigned to chemical soil reclamation, the rate of which is unacceptably reduced (Table 1), and the portion and area of acid plowed soils increase. They have already been revealed in the southern regions of the country. The acidification of agricultural landscapes continues [18].

To compensate organic matter (humus) and to prevent decarbonization of soils, it is necessary to apply 
Table 1. The area of fallow lands and croplands and application of mineral fertilizers in the Russian Federation recalculated per $100 \%$ of nutrients (a.s.)

\begin{tabular}{|c|c|c|c|c|c|}
\hline \multirow{2}{*}{ Years } & \multicolumn{2}{|c|}{ Area, $\times 10^{6}$ ha } & \multicolumn{2}{|c|}{$\begin{array}{l}\text { Application of mineral } \\
\text { fertilizers per year }\end{array}$} & \multirow{2}{*}{$\begin{array}{l}\text { Application of lime } \\
\text { materials, million tons } \\
\text { of physical mass per year }\end{array}$} \\
\hline & $\begin{array}{l}\text { of black } \\
\text { fallows }\end{array}$ & of crops & $\begin{array}{l}\text { million tons } \\
\text { of a.s. }\end{array}$ & $\begin{array}{l}\mathrm{kg} \text { of a.s./ha } \\
\text { of crops }\end{array}$ & \\
\hline $1971-1975$ (mean) & 9.7 & 122.5 & 6.0 & 49.0 & 14.0 \\
\hline 1976-1980 (mean) & 8.4 & 124.2 & 8.7 & 70.0 & 20.8 \\
\hline $1981-1985$ (mean) & 12.0 & 119.5 & 10.9 & 91.2 & 27.4 \\
\hline 1986-1990 (mean) & 14.2 & 118.0 & 13.0 & 110. & 31.0 \\
\hline $1991-1995$ (mean) & 15.1 & 109.9 & 5.3 & 48.2 & 16.0 \\
\hline $1996-2000$ (mean) & 18.0 & 92.2 & 1.4 & 15.2 & 2.0 \\
\hline $2001-2005$ (mean) & 16.2 & 79.7 & 1.4 & 17.6 & 2.5 \\
\hline 2006 & 13.8 & 75.3 & 1.5 & 19.9 & 2.3 \\
\hline 2007 & 13.6 & 74.8 & 1.7 & 22.7 & 2.1 \\
\hline 2008 & 13.7 & 76.9 & 1.9 & 24.7 & 2.3 \\
\hline 2009 & 14.0 & 77.8 & 1.9 & 24.4 & 1.8 \\
\hline 2010 & 14.7 & 75.2 & 1.9 & 25.4 & 2.0 \\
\hline $2006-2010$ (mean) & 14.0 & 76.0 & 1.8 & 23.7 & 2.1 \\
\hline 2011 & 14.0 & 76.7 & 2.0 & 24.9 & 2.0 \\
\hline 2012 & 14.0 & 76.3 & 1.9 & 24.9 & 2.2 \\
\hline 2013 & 12.5 & 78.1 & 1.8 & 23.0 & 2.1 \\
\hline 2014 & 12.4 & 77.8 & 1.9 & 24.4 & 2.3 \\
\hline 2015 & 11.9 & 78.6 & 2.0 & 25.4 & 2.1 \\
\hline $2011-2015$ (mean) & 13.0 & 77.5 & 1.9 & 24.5 & 2.1 \\
\hline 2016 & 12.0 & 79.3 & 2.3 & 29.0 & 1.9 \\
\hline 2017 & 11.8 & 80.0 & 2.5 & 31.3 & 2.1 \\
\hline 2018 & 12.0 & 79.6 & 2.5 & 31.4 & 2.5 \\
\hline 2019 & 11.6 & 79.7 & 2.8 & 35.1 & 2.6 \\
\hline 2020 (predicted) & 11.8 & 80.3 & 2.9 & 36.1 & 4.6 \\
\hline 2016-2020 (mean, predicted) & 11.8 & 79.8 & 2.6 & 32.6 & 2.7 \\
\hline
\end{tabular}

*Explanations for the Table are in the text.

on the average 6-7 t/ha of organic fertilizers per year (or about 550-640 $\times 10^{6} \mathrm{t}$ in total) to the rotated land. The amount of traditional organic fertilizers decreases. The number of livestock dropped from 76 million in 1990 to $35 \times 10^{6}$ conditional heads in 2019. Manure production was $886 \times 10^{6} \mathrm{t} 30$ years ago, and $390 \times 10^{6} \mathrm{t}$ were applied to the soil (44\%). At the present time, the application does not exceed $70 \times 10^{6} \mathrm{t}(30 \%)[10,11$, 13]. The rate of organic fertilizers per conventional head of livestock in farms of all categories was $6.5 \mathrm{t}$ (including $5.2 \mathrm{t}$ of litter manure and $1.3 \mathrm{t}$ of peat) in 1990 and is less than $2.0 \mathrm{t}$ now. Peat is not used at all.

All this in combination causes a drop in the efficiency of agricultural technologies and in the stability of agrocenoses, a shortage of potential agricultural products, and a decrease in their quality. Soils lose their fertility and degrade. The rotation of nitrogen-, phosphorus-, and carbon-containing wastes (secondary resources) is uncontrolled, and they pollute environmental objects.

Let us considered an example. The removal of the main elements from soil during the production of $1 \mathrm{t}$ of grain and of the corresponding amount of by-products depends on the soil, climatic conditions, crop, and its variety and averages $25-35,11-15$, and $20-27 \mathrm{~kg}$ recalculated per $\mathrm{N}, \mathrm{P}_{2} \mathrm{O}_{5}$, and $\mathrm{K}_{2} \mathrm{O}$, respectively. In addition, 6-10 kg of calcium and 6-8 kg of magnesium, sulfur, silicon, microelements, and others are removed. The higher the yield, the greater is the removal. The latter rises, when we get high-quality grain with a high protein and gluten content. Harvesting of $100 \times 10^{6} \mathrm{t}$ of cereals is accompanied by removal of $3.0 \times 10^{6} \mathrm{t}$ of nitrogen, $1.2 \times 10^{6} \mathrm{t}$ of phosphorus, and $2.3 \times 10^{6} \mathrm{t}$ of potassium $\left(6.5 \times 10^{6} \mathrm{t}\right.$ in total $)$. This is added by $1 \times 10^{6} \mathrm{t}$ of calcium and $0.8 \times 10^{6} \mathrm{t}$ of mag- 
nesium. These data may be compared with the volume of agrochemical substances used (Table 1). It should be taken into account that in addition to the projected grain harvest of $120-125 \times 10^{6} \mathrm{t}$ in 2020 , other crop products will be harvested.

The mean export of grain from Russia amounted to more than $40 \times 10^{6} \mathrm{t} /$ year over the past five-year period. In the past agricultural year (July 1, 2019June 30, 2020), Russia exported $43 \times 10^{6} \mathrm{t}$ of grain, amounting to US $\$ 8.5$ billion. According to forecasts of the Ministry of Agriculture of the Russian Federation, in the new year starting from July 1, 2020, the export will amount to $45 \times 10^{6} \mathrm{t}$. This activity is subsidized and supported by the state, and it is the only protected item, when correcting the Decree of the Government of the Russian Federation no. 717 of July 14, 2012, On the State Program for the Development of Agriculture and Regulation of Markets of Agricultural Products, Raw Materials, and Food, which is valid until 2025.

Grain and oil are exchange commodities. In 2020, the costs of ton of oil and grain on the world market became equal. Prices for many types of basic raw materials, including hydrocarbons, drop. This trend will be preserved in the medium-term period, and the cost of grain and other agricultural products will increase. Soils of Russia are its main but still undervalued wealth, which is the basis for its sustainable lowcarbon development at present and in future.

The achievement of food security in the country and the export of food products and agricultural raw materials are related to uncompensated expenditures of soil fertility reserves: a natural resource credit, which increases every year. Agricultural exports can be considered as the export abroad of the basis of soil fertility: millions of tons of macro- and microelements of plant mineral nutrition, including strategic phosphorus, which is scarce all over the world. The amount of phosphorus-containing compounds available for plants in soil in most cases determine the yield limit. Optimization of mineral nutrition of plants is provided by fertilizers, by phosphorous in particular. This is the case for all cultures. The reclamation method of phosphorization consists in the application of local agroores with a low content of this element into the soil, which reduces the consequences of the lack of phosphorus fertilizers $[1,3,14]$. The accumulation of mobile phosphorus in the top root layer of soils is one of the factors of a large-scale reproduction of their fertility.

\section{Regional Food Systems (Problems of Organization of Functioning and Rational Use of Soil Resources)}

A state administrative body specifically authorized in the area of land use is absent at the present time. As a result, two state land monitoring procedures are applied. The decree of the Government of the Russian
Federation no. 450 of June 12, 2008, On the Ministry of Agriculture of the Russian Federation, assigns these functions and powers, concerning agricultural lands, to this Ministry.

Their total area in Russia is $382.5 \times 10^{6}$ ha, including 197.7 (Federal Service for State Registration) or $222.0 \times 10^{6}$ ha (Federal State Statistics Service) of the most valuable (agricultural) lands. In 2019, the crop area was $79.9 \times 10^{6} \mathrm{ha}$, and the area of fallow lands was 11.6 million ha (Table 1), although the statistical area of plowed land was $115.8 \times 10^{6}$ ha $\left(116.2 \times 10^{6}\right.$ ha according to the Federal Service for State Registration). In 1990, there were $117.7 \times 10^{6}$ ha of croplands and $13.8 \times 10^{6}$ ha of fallow $\left(131.5 \times 10^{6}\right.$ ha in total, which corresponded to the area of arable land) $[5,10$, 11, 13]. Official data of the Federal Service for State Registration, the Ministry of Agriculture, and Federal State Statistics Service often differ. We cannot expect anything else, because most of them is received in terrain conditions by questionnaires. The analysis of the data shows the lack of complete and objective information even in the system of registration of rights and of storage and accounting of real estate, not to mention soils and their status.

The Decree of the Government of the Russian Federation no. 1292-r of July 30, 2010, On Approval of the Concept for the Development of State Monitoring of Agricultural Land and Land Used or Provided for Farming as Components of Other Categories of Land, and the Formation of State Information Resources on These Lands for the Period to 2020, points out that soil fertility continues to decrease in most areas of Russia. The soil cover of agricultural lands undergoes degradation and pollution and loses its resistance to destruction and the ability to restore properties and fertility. The performed monitoring does not provide the control of land plots and fields of crop rotation as a productive resource. It does not include a number of parameters, which characterize soil fertility and are essential for agricultural production.

According to the Order of the Ministry of Agriculture of the Russian Federation no. 664 of December 24, 2015, On Approval of the Procedure for State Monitoring of Agricultural Land, monitoring is a system of operational, periodic, and basic (initial) survey of changes in the qualitative and quantitative status of agricultural lands, including their fertility. It is specified into land use monitoring and land status monitoring.

The Order of the Government of the Russian Federation no. 297-r of March 3, 2012, approves the Principles of State Policy of the Use of the Land Fund of the Russian Federation for 2012-2020. It determines the goals of the state policy on management of the land fund: higher efficiency of land use and protection of land as the main component of the environment and the main means of agricultural production for ensuring food security of the country. The results of the implementation of this document have not yet been 
summed up, but the terms soil and soil resources are absent in it.

Federal law no. 78-FZ of June 18, 2001, On Land Management (hereinafter referred to as 78-FZ), is not active now: at the revision of 2008, the concept of territorial land management was excluded from it.

Soil, geobotanical, and other surveys should be performed in order to obtain data on the status of lands, including soil, as well as to identify lands undergone water and wind erosion, mudslides, flooding, waterlogging, secondary salinization, aridization, compaction, pollution by production and consumption waste and radioactive and chemical substances, contamination, and other negative impacts (article 11). The study of land status (article 9), including soil, geobotanical, and other surveys, should be based on geodetic and cartographic materials (article 10). (The question is: by whom and by what forces and means should this activity be performed?)

The Federal Service for State Registration, Cadastre, and Cartography (Rosreestr) is directly managed by the Government of the Russian Federation (Decree of the President no. 21 of January 21, 2020, On the Structure of Federal Executive Bodies). The Service is authorized to perform land management according to the decisions of Federal State Authorities (paragraph 5.2.2), federal state supervision in the area of land management (paragraph 5.1.12), state monitoring of lands in the Russian Federation (except for agricultural lands) (paragraph 5.1.13), and state land supervision (paragraph 5.1.14). (Decree of the Government of the Russian Federation no. 457 of June 1, 2009, On the Federal Service for State Registration, Cadastral Issues, and Cartography).

Rosreestr is not authorized to manage land and soil resources and is not responsible for their irrational use. In practice, it does not perform soil survey, study, and mapping, as stipulated in the aforementioned articles 9, 10 , and 11 of in $78-\mathrm{FZ}$. Means for these activities are absent.

There are no requirements for rural areas in the Russian Federation for mandatory land management everywhere, where agriculture is developed (or is temporarily absent). In the existing schemes of territorial planning of municipal districts and on general plans of settlements and urban districts, agricultural lands are represented as one massif without zoning and corresponding rules of land use.

Paragraph 19 of the Order of the Government of the Russian Federation no. 2413-r of November 8, 2018, On Approval of the Action Plan for the Improvement of the Legal Regulation of Land Relations, provides introduction of the institute of certification of land plots in the composition of agricultural lands until August 1, 2019. This should provide the account of data on the status and properties of soils on them. This provision has not been implemented up to now, and this cannot be done correctly.
In September 2019, the draft law № 681101-7 On Amendments to Certain Legislative Acts of the Russian Federation to Improve Legal Regulation of Relations in the Protection of Agricultural Land passed the first reading at the State Duma. As a result of the amendments, the notion of soil and its derivatives were deleted from the text (Federal Law no. 308-FZ of July 31, 2020, On Amendments to Article 22 of the Federal Law On Safe Handling of Pesticides and Agrochemicals and the Federal Law On State Regulation of Ensuring the Fertility of Agricultural Lands).

\section{CONCLUSIONS}

The preservation of the ecological functions of the soil cover is an obligatory condition for the sustainable development and existence of the Earth's biosphere. Its status all over the planet, including currently used lands and those newly introduced into or excluded from agricultural use, determines the time of the beginning and the rate of ecological risks, as well as of risks and threats to food security. Soil is the basis of food systems at all levels, from the global to local.

The global role and value of soil resources increases due to the widely spread processes of their degradation and loss, as well as to the fact that the soil cover of the world cannot perform the required biosphere functions. The emerging green economy is aimed at preserving biodiversity and achieving sustainable development goals. In particular, the proposed climateneutral agriculture guarantees the reproduction of soil fertility, the maximal use of the resources of organic matter, including animal waste, and the prevention of a decrease in humus reserves in arable soils (decarbonization) and their degradation, including all types of erosion.

Russia is characterized by the maximal area of soil cover: about $14.5 \times 10^{6} \mathrm{~km}^{2}$, or one-sixth of the planetary area. Soils are a unique national wealth and strategic resource, which is undervalued and is not rationally and carefully used. The amount of applied fertilizers and ameliorants is insufficient to reproduce the fertility of plowed soils.

Food security in the country and the export of food products are achieved by uncompensated use of the soil fertility reserve: natural resource credit, the volume of which increases every year. Agricultural exports may be considered as the export of the basis of soil fertility: millions of tons of macro- and microelements of plant mineral nutrition, including strategic phosphorus, the amount of which is insufficient all over the world.

There are no state documents that would clearly and unambiguously determine the area and location of arable soils and agricultural land in Russia necessary for modern agricultural production and execution of tasks of the sustainable development goals. The current legal regulation does not give a clear idea of the 
place of soils, soil cover, and soil resources in the organization of land use, implementation of land policy, management of agricultural production, and formation of the national food system with the account of the requirements of the SDGs.

The urgent problems include:

(i) the need to introduce into Russian law a complete, scientifically based, legally valid, precise, uniquely determined, conventional, and contextindependent definition of soil and its fertility as a fundamental unique property;

(ii) the definition of land management for agricultural production as a combination of measures for studying soil status and for planning and organizing their rational use and protection;

(iii) the correct determination of the kinds of permitted use of soils on croplands, which are the most important part of agricultural land, as well as the definition of the concepts of intended, permitted, and rational use of soils and of a significant decrease in their fertility.

In this regard, the State Agrochemical Service of the country could become a soil-agrochemical service and perform all the works on environmental monitoring of soils and agricultural lands, of plowed soils and croplands in particular.

\section{ACKNOWLEDGMENTS}

The article was prepared and published in the new section of the journal: Materials for Discussion. We hope that the author statements deserve an interested discussion by scientists and experts.

\section{COMPLIANCE WITH ETHICAL STANDARDS}

Conflict of interests. The authors declare that they have no conflicts of interest.

Statement on the welfare of humans or animals. This article does not contain any studies involving animals performed by any of the authors.

\section{REFERENCES}

1. Agroecological and Other Innovative Approaches for Sustainable Agriculture and Food Systems That Enhance Food Security and Nutrition, HLPE, Rome: FAO, 2019.

2. Dobrovol'skii, G.V., Karpachevskii, L.O., and Kriksunov, E.A., Geosfery i pedosfera (Geosheres and Pedosphere), Moscow, 2010.

3. Dobrovol'skii, G.V. and Nikitin, E.D., Sokhranenie pochv kak nezamenimogo komponenta biosfery: funktsional'no-ekologicheskii podkhod (Soil Safe as an Indispensable Biosphere Component: Functional-Ecological Approach), Moscow, 2000.

4. Dobrovol'skii, G.V. and Nikitin, E.D., Ekologiya pochv. Uchenie ob ekologicheskikh funktsiyakh pochv: Uchebnik
(Soil Ecology. Soil Ecological Functions. Student's Book), Moscow, 2006.

5. Doklad o sostoyanii $i$ ispol'zovanii zemel' sel'skokhozyaistvennogo naznacheniya Rossiiskoi Federatsii v 2017 godu (Report on Agriculture Lands State and Application in Russia in 2017), Moscow, 2019.

6. Kovda, V.A., Soils pathology and planet's biosphere safe, Biosfera, 2011, vol. 3, no. 4.

7. Meadows, D.H., Meadows, D.L., and Randers, J., Beyond the Limits, Chelsea Green Publ., 1992.

8. Food Security and Nutrition Building a Global Narrative towards 2030, HLPE, Rome, 2018.

9. Nutrition and Food System, HLPE, Rome, 2018.

10. Rossiiskii statisticheskii ezhegodnik. 2019: Stat. sb. (Russian Statistical Yearbook for 2019), Moscow, 2019.

11. Rossiya v tsifrakh. 2020: Kratkii stat. sb. (Russia in Figures. 2020. Brief Statistical Digest), Moscow, 2020.

12. Rossiya i strany mira. 2018: statisticheskii sbornik (Russia and World Countries in 2018. Statistical Digest), Moscow, 2018.

13. Sel'skoe khozyaistvo v Rossii. 2019: Kratkii statisticheskii sbornik (Agriculture in Russia in 2019. Brief Statistical Digest), Moscow, 2019.

14. Sushenitsa, B.A., Fosfatnyi uroven' pochv i ego regulirovanie (Soil Phosphate Layer and Ways for Controlling It), Moscow, 2007.

15. Titova, V.I., Ways for choosing indexes and experience for estimation soil coating ability to perform general biosphere functions: Analytical review, Agrar. Nauka Evro-Severo-Vostoka, 2018, vol. 67, no. 6.

16. Khaziev, F.Kh., Soil and ecology, Vestn. Akad. Nauk Resp. Belarus, 2017, vol. 24, no. 3.

17. Khar'kina, M.A., Soil fertility and its role in preserving living on the Earth, Energ., Ekon., Tekh., Ekol., 2017, no. 7.

18. Khomyakov, D.M., Natural environment acidity change and soils liming in regions with humid climate, Agrokhimiya, 2000, no. 3.

19. Bringezu, S., Schütz, H., Pengue, W., et al., Assessing global land use: Balancing consumption with sustainable supply, A Report of the Working Group on Land and Soils of the International Resource Panel, 2014.

20. Cremadesa, R. et al., Ten principles to integrate the water-energy-land nexus with climate services for coproducing local and regional integrated assessments, Sci. Total Environ., 2019, vol. 693, p. 133662.

https://doi.org/10.1016/J.SCITOTENV.2019.133662

21. Global Food Policy Report: Building Inclusive Food Systems, Washington, 2020.

22. Hatfield, J.L., Sauer, Th.J., and Cruse, R.M., Soil: The forgotten piece of the water, food, energy nexus, $A d v$. Agron., 2017, vol. 143.

https://doi.org/10.1016/bs.agron.2017.02.001

23. Keesstra, S.D., et al., The significance of soils and soil science towards realization of the United Nations sustainable development goals, Soil, 2016, vol. 2, pp. 111-128. https://doi.org/10.5194/soil-2-111-2016

24. Land Restoration for Achieving the Sustainable Development Goals: an International Resource Panel Think Piece, Nairobi, 2019. https://www.resourcepanel.org/ 
file/1272/download?token=guufxUz3. Cited April 20, 2020.

25. MAGIC Nexus Policy Brief: Soil as the "missing link" for the Water-Energy-Food-Environment Nexus. https://www.water-energy-food.org/resources/resourcesdetail. Accessed April 20, 2020.

26. OECD-FAO Agricultural Outlook 2019-2028, Rome, 2019.

27. Olawuyi, D., Sustainable development and the waterenergy-food nexus: legal challenges and emerging solutions, Environ. Sci. Policy, 2020, vol. 103, pp. 1-9. https://doi.org/10.1016/j.envsci.2019.10.009

28. Soil and Sustainable Development Goals, Lal, R., Eds., Stuttgart, 2018.
29. Status of the World's Soil Resources: Main Report, Rome: UN Food Agric. Org., 2015.

30. The International Code of Conduct for the Sustainable Use and Management of Fertilizers, Rome: FAO, 2019.

31. The State of Food Security and Nutrition in the World. Safeguarding against Economic Slowdowns and Downturns, Rome: UN Food Agric. Org., 2019.

32. The Water-Energy-Food, Nexus. A New Approach in Support of Food Security and Sustainable Agriculture, Rome, 2014.

33. Voluntary Guidelines for Sustainable Soil Management, Rome: UN Food Agric. Org., 2017.

Translated by I. Bel'chenko 